\title{
Antifungal Activity and Chemical Composition of Neem Seed Extract (Azadirachta indica A.)
}

\author{
Lulu Chang, ${ }^{\mathrm{a}}$ Yin Liu, ${ }^{\mathrm{a}}$ Weiwei Zhang, ${ }^{\mathrm{a}}$ Guoqi Xu, ${ }^{\mathrm{b}}$ Lihai Wang, ${ }^{\mathrm{b}, *}$ and Wenxia Yuan ${ }^{\mathrm{a}, *}$
}

The antifungal activities and chemical composition of neem seed extract (Azadirachta indica) were investigated. An agar diffusion assay showed that neem seed extract (optimum concentration: 10\%) inhibited the growth of Trametes versicolor and Gloeophyllum trabeum. The minimum inhibitory concentration and minimum fungicidal concentration were $2 \%$ and $4 \%$, respectively, against the two fungal species. Scanning electron microscopy revealed severe morphological damage to fungal hyphae, including reduction of spores and hyphal shriveling. Fourier transform infrared spectroscopy and gas chromatography-mass spectrometry analyses identified 17 compounds that represented $80.3 \%$ of the total extract, including astaxanthin (34.3\%), cinobufagin (16.9\%), anodendroside A (6.65\%), 16-acetoxy-4,8,14-trimethyl-3,11-dioxo-, methyl ester (5.09\%). Furthermore, T. versicolor-infected wood and G. trabeuminfected wood treated with $10 \%$ neem seed extract displayed mass decreases of $11.4 \pm 5.8 \%$ and $25.8 \pm 7.5 \%$, respectively, compared with distilled water treatment $(21.6 \pm 4.2 \%$ and $46.9 \pm 4.3 \%$, respectively). These findings suggest the potential use of neem seed extract for antifungal wood protection.

DOI: 10.15376/biores.17.1.592-603

Keywords: Neem seed; Extract; Antifungal activity; Chemical composition

Contact information: a: Basic Experimental Centre for Natural Science, University of Science and Technology, 100083 Beijing, China; b: School of Engineering and Technology, Northeast Forestry University, 150040 Haerbin, China;

*Corresponding authors: lihaiwang@yahoo.com; wxyuan@ustb.edu.cn

\section{INTRODUCTION}

The quality of wood products is seriously affected by fungi. Approximately $15 \%$ of wood production is lost due to fungal decay in China (Ma et al. 2015). Wood rot fungi such as Trametes versicolor and Gloeophyllum trabeum can degrade lignin, cellulose, and hemicellulose, drastically reducing the quality and changing the mechanical properties of wood (Blanchette 1991; Fabbri et al. 1997; Machado 2013; Meyer and Brischke 2015). Therefore, protecting wood from fungal rot is of critical importance.

Chinese white poplar (Populus tomentosa) belongs to the section Populus (Leuce) of the Populus genus, and is widely distributed along the Yellow River. Due to its lower contents of fermentation-inhibiting extractives and higher biomass conversion efficiency, it has become one of the most commercially significant tree species in China (Du et al. 2014). However, the applications of $P$. tomentosa are limited by its poor decay resistance (Zhao et al. 2021). Nowadays, the most widely used wood preservatives, such as chromated copper arsenate, are harmful to the environment and human health (Hastrup et al. 2005). Thus, it is necessary to develop an effective, eco-friendly wood preservative. 
The effective antifungal components of many natural preservatives are secondary plant metabolites (Xu et al. 2013). The use of natural plant extracts as wood fungicides has become a research focus, considering that plant-derived wood preservatives are non-toxic and efficient, with broad-spectrum activity. Azadirachta indica A. Juss., known as neem, is an evergreen medicinal plant native to India and Myanmar. Neem extract has been reported to be effective against wood infestation by termites, including Reticulitermes speratus Kolbe (Serit et al. 1992), and Coptotermes curvignathus Hohngren (Sajap et al. 2006). Neem extract is also used as an antibacterial agent against Staphylococcus aureus, Staphylococcus pyogenes, Escherichia coli, and Pseudomonas aeruginosa (El-Mahmood et al. 2013). Furthermore, neem oil shows antifungal effects against Trametes versicolor and Postia placenta when applied to chir pine wood (Pinus roxburghii Sargent) (Dhyani and Tripathi 2006). Mango tree wood (Mangifera indica) and rain tree wood (Albizia saman) treated with neem extract showed 6 to 7 times higher decay resistance than untreated wood against Schizophyllum commune (Islam and Shams 2009). Despite the common use of neem extract as an antimicrobial, few studies have reported on its antifungal activities in $P$. tomentosa wood.

In this study, neem seed extract was tested for antifungal activity against two kinds of fungi that cause severe damage to wood. The morphological changes of the fungi were observed by scanning electron microscope (SEM), and the chemical composition of the extract was elucidated via Fourier transform infrared (FTIR) spectroscopy and gas chromatography-mass spectrometry (GC/MS).

\section{EXPERIMENTAL}

\section{Materials}

Neem seeds were collected in Kunming (Yunnan, China) during July of 2019. The seeds were washed and inside air-dried for one week. The wood fungi under investigation, Trametes versicolor and Gloeophyllum trabeum, were obtained from the Chinese Strain Preservation Center (Beijing, China). The fungi were preserved in potato dextrose agar (PDA) and stored at $4{ }^{\circ} \mathrm{C}$. The experimental tree $(P$. tomentosa) grew in the Yichun area in Heilongjiang province. Sapwood samples $(20 \mathrm{~mm} \times 20 \mathrm{~mm} \times 10 \mathrm{~mm})$ were dried to constant weight at $105^{\circ} \mathrm{C}$.

\section{Preparation of Neem Seed Extract}

The neem seeds were ground to $20-$ mesh. A total of $20 \mathrm{~g}$ of neem powder was mixed with $280 \mathrm{~mL}$ of $60 \% \mathrm{v} / \mathrm{v}$ ethanol solution (Chang et al. 2018). The mixture was stirred in a water bath at $50{ }^{\circ} \mathrm{C}$ for $90 \mathrm{~min}$. The residual ethanol was evaporated using a vacuum rotary evaporator (RE52AA; Huanyu, Zhejiang, China). The extracts were stored at $4{ }^{\circ} \mathrm{C}$ for further use.

\section{Agar Diffusion Assay}

Petri dishes containing $15 \mathrm{~mL}$ of PDA were used for the antifungal activity assay, conducted on solid media using the disk diffusion method (Bajpai et al. 2008). The PDA solution was prepared using sterile distilled water, serially diluted, and added at final concentrations of $0.5 \%, 1 \%, 5 \%, 10 \%$, and $15 \%$ to 5 -mm diameter holes punched in the agar. The plates were incubated at $26^{\circ} \mathrm{C}$ for 5 to 7 days. The inhibition zone were measured using a vernier caliper. 


\section{Determination of Minimum Inhibitory Concentration (MIC) and Minimum Fungicidal Concentration (MFC)}

The MICs of the neem seed extract against $T$. versicolor and G. trabeum were determined using the twofold dilution method (Fernández et al. 2000). A small amount of mycelium was mixed with sterile distilled water in test tubes. The turbidimetric method was used to obtain a homogeneous spore suspension of $1 \times 10^{6} \mathrm{CFU} / \mathrm{mL}$ using McFarland standards (Liu et al. 2021). The neem seed extract was dissolved in sterile distilled water and diluted; the extract was added to potato dextrose broth (PDB) to obtain final concentrations of $4 \%, 2 \%, 1 \%, 0.5 \%, 0.25 \%, 0.125 \%, 0.0625 \%, 0.0313 \%$, and $0.0156 \%$. Next, $1 \mathrm{~mL}$ of each fungal suspension was cultured in a test tube in PDB for 24 to $72 \mathrm{~h}$ at $26^{\circ} \mathrm{C}$. The blank controls were test tubes containing only PDB, while the negative controls were test tubes inoculated with the fungal spore suspension. According to the Clinical and Laboratory Standards Institute (CLSI 2012), the MIC is indicated by the test tube without observable fungal growth (precipitation or surface growth or internal turbidity).

The minimum fungicidal concentration (MFC) was determined using the drugcontaining medium method. Extract solutions of different concentrations were prepared according to the concentration gradient: $\mathrm{MIC}+2 \%, \mathrm{MIC}+1 \%$, and MIC. Next, $1 \mathrm{~mL}$ of neem seed extract was mixed with $9 \mathrm{~mL}$ of melted PDA in the dish. And the 5-mm fungal cakes were cut from the dishes and inoculated on the drug-containing dish and incubated at $26^{\circ} \mathrm{C}$ for 3 to 5 days. The concentration at which fungal growth was suppressed in the plate represented the MBC.

\section{Effect of Neem Seed Extract on Hyphal Morphology}

Mycelial plugs from the periphery of the fungal colonies were fixed in $2.5 \%$ glutaraldehyde $(\mathrm{pH} 7.4)$ and cultured at $4{ }^{\circ} \mathrm{C}$ for $12 \mathrm{~h}$. The mycelia were washed with 0.1 $\mathrm{M}$ phosphate buffer ( $\mathrm{pH}$ 7.4) for $5 \mathrm{~min}$. The samples were dehydrated in ethanol solutions (once in 30, 50, 70, 80, 90, and 95\% v/v ethanol, and three times in $100 \%$ ethanol for 20 min each) and dried at $25{ }^{\circ} \mathrm{C}$ for $24 \mathrm{~h}$ (Chen et al. 2017). The samples were sputter-coated with gold, and subsequently observed using a SEM (FEI Quanta-200; FEI Company, Hillsboro, OR, USA).

\section{FTIR Analysis of Extract}

Neem seed extract was analyzed using a Nicolet iS10 instrument (Thermo Fisher Scientific, Madison, WI, USA). A tablet was prepared by mixing $10 \mathrm{mg} \mathrm{KBr}$ and $300 \mathrm{mg}$ neem seed extract, grinding the mixture to a powder, and compressing the powder under 200 bars of pressure. The FTIR spectra of the tablet were analyzed using Spectrum One software (ver. 5.0.1, Sacramento, CA, USA) (Sun et al. 2011).

\section{GC/MS Analysis of Extract}

The chemical composition of neem seed extract was analyzed by GC/MS (HP6890GC/5973MSD; Agilent Technologies, Santa Clara, CA, USA) fitted with a HP-5 capillary column $(30 \mathrm{~m} \times 0.32 \mathrm{~mm} \times 0.2 \mu \mathrm{m}$ film thickness $)$. The initial oven temperature was $190{ }^{\circ} \mathrm{C}$, which was increased by $5{ }^{\circ} \mathrm{C} / \mathrm{min}$ to $250{ }^{\circ} \mathrm{C}$, held isothermal for $10 \mathrm{~min}$. Helium was the carrier gas. Electron ionization mass spectra were collected at $70 \mathrm{eV}$ ionization voltages from $\mathrm{m} / \mathrm{z}, 10$ to 350 in full scan mode. The National Institute of Standards and Technology spectrum library and manual analysis were used for serial retrieval and the obtained mass spectrograms. The peak area normalization method was used to obtain the relative content of each component. 


\section{Wood Decay Test}

Wood impregnation with neem seed extract

Samples of $P$. tomentosa were treated with neem seed extract at a relative vacuum of $-0.09 \mathrm{MPa}$ for $30 \mathrm{~min}$, after which the vacuum was released. The blocks were removed from the treatment solution, and wiped lightly to clean the surfaces. The samples were weighed (to the nearest $0.01 \mathrm{~g}$ ) to determine the degree of treatment solution retention in each sample. The drug loading rate was calculated using the following formula,

$$
R=\left(m_{2}-m_{1}\right) c \times 10 / V\left(\mathrm{~kg} \cdot \mathrm{m}^{-3}\right)
$$

where $m_{1}, m_{2}, c$, and $V$ represent the sample weight before and after treatment, the mass of preservatives solution in $100 \mathrm{~g}$ of the treatment solution, and the block volume, respectively. After the blocks were dried to constant weight at $45{ }^{\circ} \mathrm{C}$, they were sterilized for $30 \mathrm{~min}$, and subsequently placed in a $500-\mathrm{mL}$ flask for the decay test.

\section{Decay test}

The treated wood samples were tested for decay resistance according to Chinese Standard GB/T 13942.1-2009 (2009). White-rot fungi (T. versicolor) and brown-rot fungi (G. trabeum) were cultured in 250-mL glass flasks. The wood blocks were inoculated in bottles containing active cultures of either T. versicolor or G. trabeum. Nine replicate experiments were performed for each treatment. The bottles were incubated for 12 weeks at $26^{\circ} \mathrm{C}$ and $75 \%$ relative humidity. After incubation, the test samples were removed from the culture flasks and dried at $45^{\circ} \mathrm{C}$ to constant weight, and then weighed to the nearest $0.01 \mathrm{~g}$. The mass loss of each block was calculated using the following formula,

$$
\text { Mass loss }(\%)=\left[\left(m_{3}-m_{4}\right) / m_{3}\right] \times 100
$$

where $m_{3}$ and $m_{4}$ represent dry mass before and after the test, respectively.

\section{RESULTS AND DISCUSSION}

\section{Antifungal Activity of Neem Seed Extract}

The neem seed extract displayed moderate to high antifungal activity against both fungi. The extract at $1 \%$ concentration exhibited weak inhibitory effects on the growth of T. versicolor (inhibition zone: $8.31 \pm 1.0 \mathrm{~mm}$ ) and G. trabeum (inhibition zone: $8.44 \pm 0.5$ $\mathrm{mm}$ ) (Table 1).

Table 1. Means of Inhibition Zones ( $\mathrm{mm}$ ) of Neem Seed Extract against Growth of Trametes versicolor and Gloeophyllum trabeum

\begin{tabular}{|c|c|c|c|c|c|c|}
\hline \multirow{2}{*}{ Fungi } & \multicolumn{7}{|c|}{ Concentration (\%) } \\
\cline { 2 - 7 } & Control & $0.5 \%$ & $1 \%$ & $5 \%$ & $10 \%$ & $15 \%$ \\
\hline $\begin{array}{c}\text { Trametes } \\
\text { versicolor }\end{array}$ & N.D. & N.D. & $8.31 \pm 1.0$ & $11.54 \pm 2.0$ & $14.31 \pm 2.5$ & $14.33 \pm 0.5$ \\
\hline $\begin{array}{c}\text { Gloeophyllum } \\
\text { trabeum }\end{array}$ & N.D. & N.D. & $8.44 \pm 0.5$ & $13.96 \pm 1.3$ & $15.91 \pm 0.9$ & $15.78 \pm 2.8$ \\
\hline N.D. = Not Detected
\end{tabular}


The largest inhibition zones on the agar plate of $T$. versicolor and G. trabeum measured $14.33 \pm 0.5 \mathrm{~mm}$ and $15.91 \pm 0.9 \mathrm{~mm}$, respectively. Notably, the extract at $10 \%$ concentration showed strong inhibitory effects against both types of fungi, while the inhibition zones decreased when using a higher concentration of extract against G. trabeum. Therefore, neem seed extract at $10 \%$ concentration was used in the follow-up wood decay test.

\section{Determination of MIC and MBC}

The MIC and MBC were used to evaluate the sensitivity of different fungi to the neem seed extract. The neem seed extract had an inhibitory effect on both fungi (Table 1), but there was no obvious inhibitory effect on either type of fungus when the concentration was under $1 \%$. In particular, T. versicolor and G. trabeum were substantially inhibited by neem seed extract at $2 \%$ concentration and $4 \%$ concentration, respectively, with no mycelial growth observed at these concentrations (Table 2). Therefore, G. trabeum was more sensitive than $T$. versicolor to the neem seed extract in vitro.

Table 2. Effects of Neem Seed Extract at Different Concentrations against Mycelial Growth of Trametes versicolor and Gloeophyllum trabeum

\begin{tabular}{|c|c|c|c|c|c|c|c|c|c|c|}
\hline \multirow{2}{*}{ Fungus } & \multicolumn{10}{|c|}{ Extract Concentration (\%) } \\
\hline & 4 & 2 & 1 & 0.5 & 0.25 & 0.0125 & 0.0625 & 0.0313 & 0.0156 & 0 \\
\hline $\begin{array}{l}\text { Trametes } \\
\text { versicolor }\end{array}$ & - & - & + & + & ++ & ++ & ++ & ++ & ++ & ++ \\
\hline $\begin{array}{c}\text { Gloeophyllum } \\
\text { trabeum }\end{array}$ & - & ++ & ++ & ++ & ++ & ++ & ++ & ++ & ++ & ++ \\
\hline
\end{tabular}
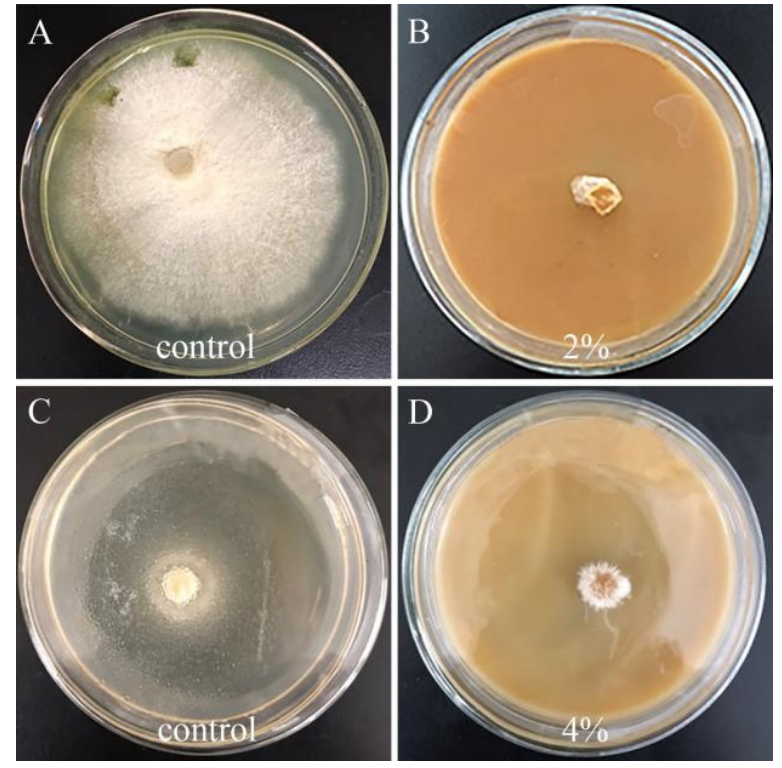

Fig. 1. Determination of minimum fungicidal concentration of neem seed extract (Azadirachta indica) against Trametes versicolor and Gloeophyllum trabeum. (A) control of T. versicolor; (B) T. versicolor treated with $2 \%$ extract; (C) control of G. trabeum; (D) G. trabeum treated with $4 \%$ extract) 
The drug-containing medium method was used to evaluate the MBC. The neem seed extract completely inhibited the mycelial growth of $T$. versicolor and G. trabeum at $2 \%$ and $4 \%$ concentration, respectively, whereas the mycelia grew well in the control medium (Fig. 1). The G. trabeum control medium was covered with mycelia and spores. There were no mycelia and spores observed in the medium except for the PDA derived from the original medium. The mycelia of G. trabeum appeared long and discontinuous, and the spores stopped growing. Therefore, the MBC of neem seed extract against $T$. versicolor and G. trabeum were $2 \%$ and $4 \%$, respectively.

\section{Effects of Neem Seed Extract on Hyphal Morphology}

The hyphal morphologies of $T$. versicolor and $G$. trabeum before and after treatment with neem seed extract were observed by SEM. In both cases, the appearance and morphology of the fungi changed after treatment with neem seed extract. The control mycelia of both fungi were thick, elongated, continuous, intact, and smooth. The spores of $T$. versicolor treated with extract were reduced remarkably, and the mycelia were thinner than control mycelia (Fig. 2 A, B). After exposure to the neem seed extract, the surface of G. trabeum mycelia appeared rough (Fig. 2 C, D). This could be explained by the damage caused to fungal cells by the extract, resulting in leakage of the cytoplasm and shrinkage of the hyphae (Soylu et al. 2010).
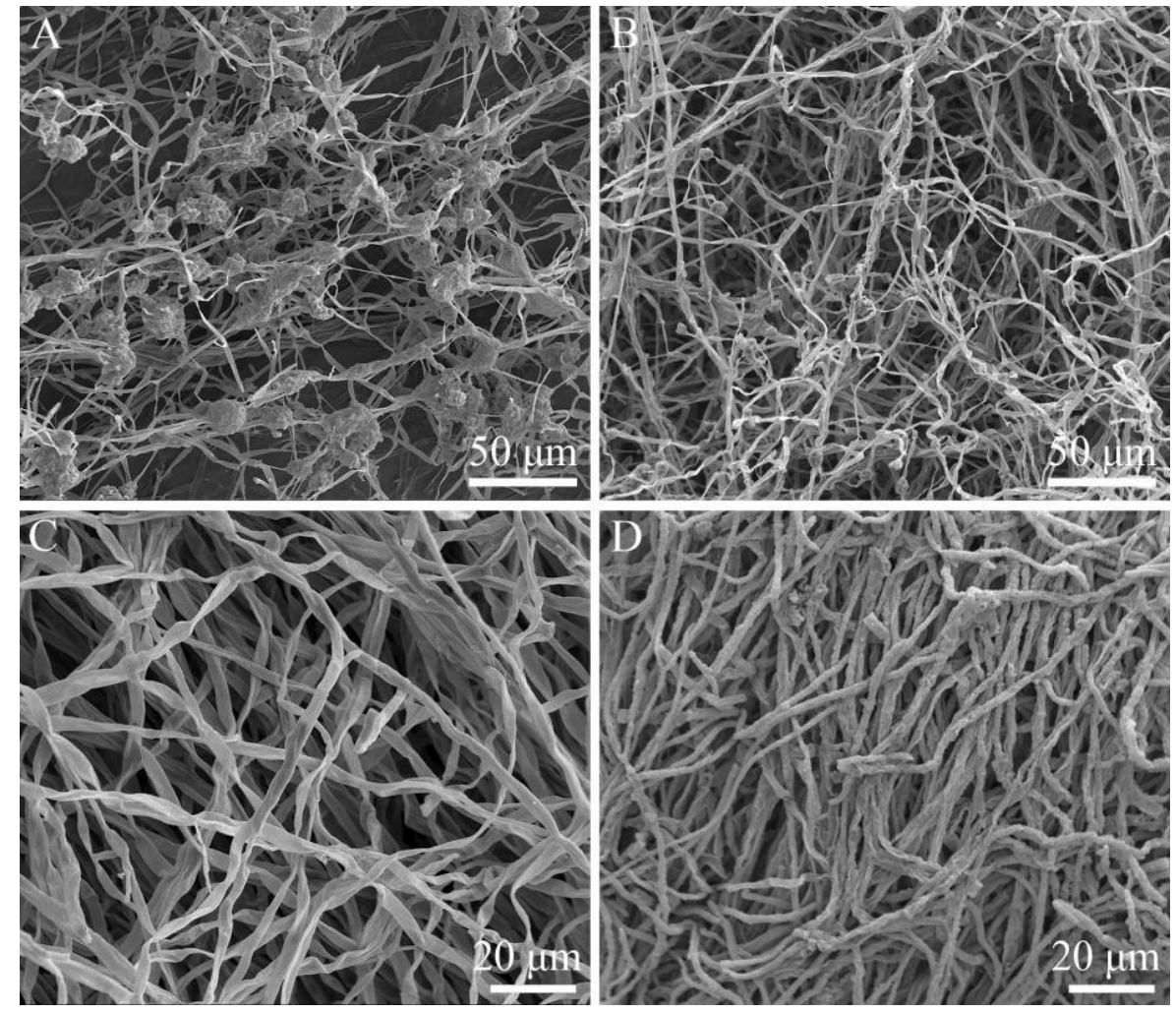

Fig. 2. Scanning electron microscope images of the hyphae of (A) Trametes versicolor (control); (B) T. versicolor treated with $2 \%$ neem seed extract; (C) control of G. trabeum; and (D) G. trabeum treated with $2 \%$ neem seed extract

\section{Antifungal Properties of Wood Treated with Neem Seed Extract}

Poplar samples that were impregnated with neem seed extract at $10 \%$ concentration and distilled water exhibited resistance to fungal attack (Table 3). The retention of neem 
seed extract by the wood samples amounted to $75.12 \pm 2.1 \mathrm{~kg} \cdot \mathrm{m}^{3}$ (Table 3 ). The average weight losses of the poplar blocks after exposure to T. versicolor and G. trabeum were 25.8 $\pm 7.5 \%$ and $46.9 \pm 3.4 \%$, respectively. Thus, the natural poplar wood belonged to the "moderately resistant class" (GB/T 13942.1, Chinese, 2009). After exposure of poplar wood samples to $T$. versicolor and $G$. trabeum, the average weight losses of poplar blocks treated with neem seed extract were $11.4 \pm 5.8 \%$ and $21.6 \pm 4.2 \%$, respectively; these values conformed to the "resistant class" (GB/T 13942.1, Chinese, 2009). The result showed that treatment with neem seed extract had inhibitory effects against both types of fungal growth in poplar wood. Furthermore, after treatment with neem seed extract, the weight loss of the T. versicolor-infected wood and G. trabeum-infected wood decreased by $14.4 \pm 1.7 \%$ and $25.3 \% \pm 0.8 \%$, respectively, compared with untreated wood. These results indicate that the neem seed extract exerted a stronger inhibitory effect against G. trabeum.

Table 3. Average Percentage of Weight Loss of Treated vs. Untreated Poplar after Exposure to Trametes versicolor and Gloeophyllum trabeum for 12 Weeks

\begin{tabular}{|c|c|c|c|}
\hline Agents & $\begin{array}{c}\text { Retention } \\
\left(\mathrm{kg} \cdot \mathrm{m}^{3}\right)\end{array}$ & $\begin{array}{c}\text { Weight loss ratio } \\
(T . \text { versicolor; } \%)\end{array}$ & $\begin{array}{c}\text { Weight loss ratio } \\
(\text { G. trabeum; \%) }\end{array}$ \\
\hline Neem seed extract & $75.12 \pm 2.1$ & $11.4 \pm 5.8$ & $21.6 \pm 4.2$ \\
\hline Distilled water & 0 & $25.8 \pm 7.5$ & $46.9 \pm 3.4$ \\
\hline
\end{tabular}

\section{FTIR Analysis of Neem Seed Extract}

The composition of neem seed extract, including its functional groups, was investigated using FTIR spectroscopy. As shown in Table 4 and Fig. 3, neem seed extract displayed absorbance peaks at 3240, 2920, 2860, 1730, 1590, 1390, 1260, 1050, 992, and $529 \mathrm{~cm}^{-1}$. The absorption bands indicate that the extract contained alkane, alkyl, alkene, alcohol, ester, carboxylic acid, aldehyde, ketone, and phenol groups. Many plant extracts contain various substances with antibacterial activity, such as terpenoids and phenolic compounds (Bouftira et al. 2010). These reactive groups may contain carbonyls $(-\mathrm{C}=\mathrm{O})$ and hydroxyls $(-\mathrm{OH})$. However, FTIR can only provide qualitative data on the extract composition; the identification of specific substances requires other methods.

Table 4. Fourier Transform Infrared Spectroscopy Analysis of Neem Seed Extract

\begin{tabular}{|c|c|c|c|c|}
\hline $\begin{array}{c}\text { Functional } \\
\text { Group }\end{array}$ & Compound Type & $\begin{array}{c}\text { Frequency Range } \\
\left(\mathrm{cm}^{-1}\right)\end{array}$ & Appearance & $\begin{array}{c}\text { Wavenumber } \\
\left(\mathrm{cm}^{-1}\right)\end{array}$ \\
\hline O-H & Alcohols, phenol & $3200-3500$ & stretch, broad & 3240 \\
\hline C-H & Alkanes & $2960-2850$ & strong, stretch & 2920 \\
\hline & Alkyl & $2870-1380$ & medium, weak & 1390,1590 \\
\hline C-O & Alkenes & $675-1000$ & - & 992 \\
\hline C=O & Alcohols, ester, & $1000-1260$ & strong, stretch & 1260 \\
\hline XH & Aldehyde, ketone & $1680-1750$ & strong & 1730 \\
\hline *Data according to Sun (2011) & $1015-1300$ & strong & 1050 \\
\hline
\end{tabular}




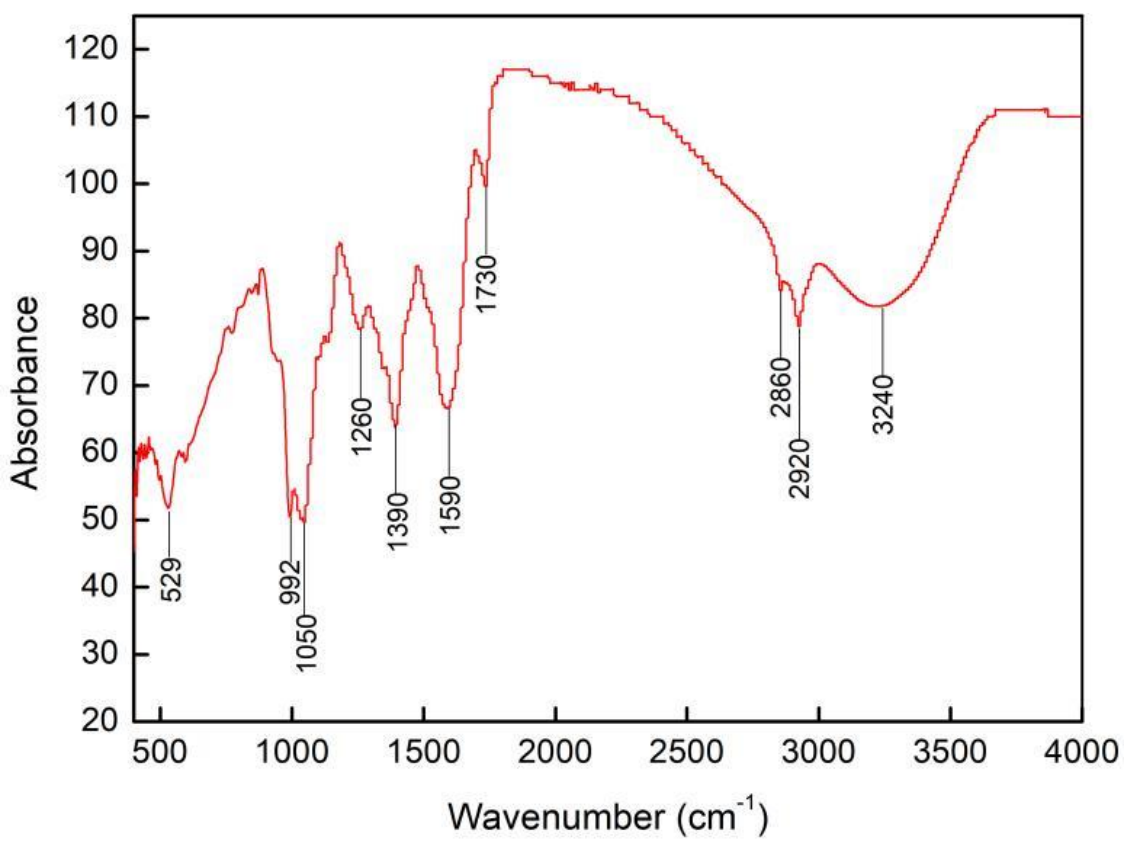

Fig. 3. Fourier transform infrared spectroscopy analysis of neem seed extract

\section{GC/MS Analysis of Neem Seed Extract}

The chemical composition of neem seed extract was determined by GC/MS (Table 5). A total of 17 compounds were isolated from the ethanolic extract, accounting for $80.31 \%$ of the total peak area, among which terpenoids, fatty acids, and sulfides were the most abundant.

Table 5. Composition of Neem Seed Extracts and the Relative Contents of 17 Components

\begin{tabular}{|c|c|c|c|}
\hline No. & Component & $\begin{array}{l}\text { Retention } \\
\text { Time } \\
\text { (min) }\end{array}$ & $\begin{array}{c}\text { Relative } \\
\text { Content } \\
(\%)\end{array}$ \\
\hline 1 & Diallyl trisulfide & 10.44 & 0.35 \\
\hline 2 & g-Hydroxy-isoeugenol & 15.72 & 0.32 \\
\hline 3 & Hexadecanoic acid & 17.35 & 0.22 \\
\hline 4 & Oleic acid & 18.96 & 0.78 \\
\hline 5 & Squalene & 24.58 & 0.09 \\
\hline 6 & Dipropyl trisulfide & 28.73 & 0.03 \\
\hline 7 & Marinobufagin & 29.86 & 4.77 \\
\hline 8 & Astaxanthin & 31.29 & 34.32 \\
\hline 9 & Pittosapogenin & 31.48 & 1.02 \\
\hline 10 & Stigmast-5-en-3-ol & 32.48 & 0.49 \\
\hline 11 & Withaferin & 33.43 & 1.97 \\
\hline 12 & Cinobufagin & 36.67 & 16.88 \\
\hline 13 & $\begin{array}{l}\text { 9(11),12-Dien-28-oic acid, 3- } \\
\text { (acetyloxy)-, methyl ester }\end{array}$ & 38.64 & 1.10 \\
\hline 14 & $\begin{array}{c}\text { 16-Acetoxy-4,8,14-trimethyl- } \\
\text { 3,11-dioxo-, methyl ester }\end{array}$ & 40.23 & 5.09 \\
\hline 15 & Khivorin & 44.16 & 0.91 \\
\hline 16 & 8,12-Di-O-acetylingol & 52.72 & 5.32 \\
\hline 17 & Anodendroside $\mathrm{A}$ & 54.07 & 6.65 \\
\hline
\end{tabular}


The main components identified in neem seed extract were astaxanthin (34.32\%), cinobufagin (16.88\%), anodendroside A (6.65\%), and 16-acetoxy-4,8,14-trimethyl-3,11dioxo-, methyl ester (5.09\%).

Astaxanthin has an inhibitory effect on bacteria including Bacillus subtilis, Salmonella typhi, Staphylococcus aureus, and Pseudomonas aeruginosa (Nath and Ravi 2013). Cinobufagin and anodendroside A display strong antioxidant effects in addition to inhibiting the growth of cancer cells (Qi et al. 2011). Diallyl trisulfide has antiparasitic activities on pathogenic protozoa including Entamoeba histolytica and Giardia lamblia (Lun et al. 1994). The neem seed extract contains various antifungal components.

\section{CONCLUSIONS}

1. Neem seed extract showed inhibitory effects against both T. versicolor and G. trabeum. In a disk diffusion assay, the largest inhibition zones on the agar plate of $T$. versicolor and $G$. trabeum were $14.33 \pm 0.5 \mathrm{~mm}$ and $15.91 \pm 0.9 \mathrm{~mm}$, respectively. Notably, neem seed extract at $10 \%$ concentration showed strong inhibitory effects against both fungi.

2. The two tested fungi were sensitive to neem seed extract, and their MIC and MFC values were both $2 \%$ and $4 \%$ against $T$. versicolor and G. trabeum, respectively.

3. The resistance of $P$. tomentosa wood treated with neem seed extract against decay caused by T. versicolor and G. trabeum was higher than that of untreated wood, such that the application of neem seed extract raised the wood samples to the "resistant class" level.

4. The extract had obvious effects on fungal morphology. For instance, the spores were decreased in number, and the mycelia became rough.

5. The absorption bands indicated that the extract contains alkane, alkyl, alkenes, alcohol, ester, carboxylic acid, aldehyde, ketone, and phenol groups. A total of 17 compounds were isolated from neem seed extract including astaxanthin $(34.32 \%)$, cinobufagin (16.88\%), anodendroside A (6.65\%), and 16-acetoxy-4,8,14-trimethyl-3,11-dioxo-, methyl ester $(5.09 \%)$.

\section{ACKNOWLEDGMENTS}

The authors are grateful for the support of the Fundamental Research Funds for the Central Universities, Grant No. FRF-TP-20-019A1.

\section{REFERENCES CITED}

Bouftira, I., Abdelly, C., and Sfar, S. (2010). "Characterization of cosmetic cream with Mesembryanthemum crystallinum plant extract: Influence of formulation composition on physical stability and anti-oxidant activity," International Journal of Cosmetic Science 30(6), 443-452. DOI: 10.1111/j.1468-2494.2008.00469.x 
Blanchette, R. A. (1991). "Delignification by wood-decay fungi," Annual Review of Phytopathology 29(1), 381-403. DOI: 10.1146/annurev.py.29.090191.002121

Bo, W. U., Zhang, Q., and Li J. Z. (2009). "Research status and development trend of wood-plastics composites," Materials Review. DOI: 10.1007/s10965-008-9216-0

Bajpai, V. K., Shukla, S., and Kang, S. C. (2008). "Chemical composition and antifungal activity of essential oil and various extract of Silene armeria L," Bioresource Technology 99(18), 8903-8908. DOI:10.1016/j.biortech.2008.04.060

Chang, L. L., Xu, G. Q., and Wang, L. H. (2018). "Preparation and antifungal activities of microcapsules of neem extract used in Populus tomentosa deteriorated by three mold fungi," BioResources 13(4), 8373-8384. DOI: 10.15376/biores.13.4.8373-8384

Chen, S. H., Ng, S. L., Cheow, Y. L., and Ting, A. S. Y. (2017). "A novel study based on adaptive metal tolerance behavior in fungi and SEM-EDX analysis," Journal of Hazardous Materials 334(15), 132-141. DOI:10.1016/j.jhazmat.2017.04.004

GB/T (2009). "Method for laboratory test of natural decay resistance of woods, (13942.12009)," Chinese Standard, Beijing, China.

CLSI (2012). "Methods for dilution antimicrobial susceptibility tests for bacteria that grow aerobically: approved standard ( $9^{\text {th }}$ Ed.)," Clinical and Laboratory Standards Institute, Wayne, USA.

Du, Q., Xu, B., Gong, C., Yang, X.-H., Pan, W., Tian, J.-X., Li, B.-L., and Zhang, D.-Q. (2014). "Variation in growth, leaf, and wood property traits of Chinese white poplar (Populus tomentosa), a major industrial tree species in Northern China," Canadian Journal of Forest Research 44(4), 326-339. DOI:10.1139/cjfr-2013-0416

Dhyani, S., and Tripathi, S. (2006). "Protection of hard and softwood through neem leaves extracts and oil: A direction towards development of eco-friendly wood preservatives," IRG/WP/06-30394. The International Research Group on Wood Protection, Stockholm.

EI-Mahmood, A. M., Ogbonna, O. B., and Raji, M. (2013). "The antibacterial activity of Azadarichta indica (neem) seeds extracts against bacterial pathogens associated with eye and ear infections," Journal of Medicinal Plants Research 4(14).

DOI:10.5897/JMPR09.169

Fabbri, A. A., Ricelli, A., Brasini, S., and Fanelli, C. (1997). "Effect of different antifungals on the control of paper biodeterioration caused by fungi," International Biodeterioration and Biodegradation 57, 61-65. DOI: 10.1016/S09648305(97)00001-2

Fernández, H., Mansilla, M., and González, V. (2000). “Antimicrobial susceptibility of Campylobacter jejuni subsp. jejuni assessed by E-test and double dilution agar method in Southern Chile," Memórias Do Instituto Oswaldo Cruz, 95(2), 247-249. DOI: $10.1590 /$ S0074-02762000000200020

Hastrup, A., Iii, F. G., Clausen, C. A., and Bo, J. (2005). "Tolerance of Serpula lacrymans to copper-based wood preservatives," International Biodeterioration and Biodegradation 56(3), 173-177. DOI:10.1016/j.ibiod.2005.06.008

Islam, M. M., and Shams, M. I. (2009). "Protective antifungal effect of neem (Azadirachta indica) extracts on mango (Mangifera indica) and rain tree (Albizia saman) wood," International Biodeterioration and Biodegradation 63(2), 241-243. DOI:10.1016/j.ibiod.2008.07.010 
Liu, Y., Jin, L., Wang, C., Sheng, J., and Song, Y. (2021). "Thymol-functionalized hollow mesoporous silica spheres nanoparticles: preparation, characterization and bactericidal activity," Bulletin of Materials Science 44(2), 1-7. DOI: 10.1007/s12034-021-02425-2

Lun, Z. R., Burri, C., Menzinger, M., and Kaminsky, R. (1994). “Antiparasitic activity of diallyl trisulfide (dasuansu) on human and animal pathogenic protozoa (Trypanosoma sp. Entamoeba histolytica and Giardia lamblia) in vitro," Annales de la Société Belge de Médecine Tropicale 74(1), 51-59. DOI: 10.1016/0001706X(94)90066-3

Ma, X. X., Jiang, M. L., and Wang, J. Y. (2015). "The climate change effects on boundaries of wood decay and termite hazard zones in China," Scientia Silvae Sinicae 51(11), 83-90. DOI:10.11707/j.1001-7488.20151111.

Meyer, L., and Rischke, B. C. (2015). "Fungal decay at different moisture levels of selected European-grown wood species," International Biodeterioration and Biodegradation 103, 23-29. DOI: 10.1016/j.ibiod.2015.04.009

Serit, M., Ishida, M., Nakata, K., Kim, M., and Takahashi, S. (1992). “Antifeeding potency of neem (Azadirachta indica) extractives and limonoids against termite (Reticulitermes speratus)," Journal of Pesticide Science 17(4), 267-273. DOI:10.1584/jpestics.17.4_267

Sun, M, Ma, X. X., Yao, Q. X., Wang, R.-C., Ma, Y.-X., Feng, G., Shang, J.-X., Xu, L., and Yang, Y.-H. (2011). "GC-MS and TG-FTIR study of petroleum ether extract and residue from low temperature coal tar," Energy and Fuels 25, 1140-1145. DOI: 10.1021/ef101610z

Machado, G. d., Cookson, L. J., Christoforo, A. L., Polito, W. L., da Silva, M. R., Calil Junior, C., and Lahr, F. A. R. (2013). "Wood preservation based on neem oil: evaluation of fungicidal and termiticidal effectiveness," Forest Products Journal 63(5), 202-206. DOI:10.1080/10549811.2016.1236277

Nath, U. U., and Ravi, R. (2013). "Isolation of astaxanthin from marine yeast and study of its pharmacological activity," International Current Pharmaceutical Journal 2(3), 67-69. DOI: 10.3329/icpj.v2i3.13584

Qi, F., Inagaki, Y., Gao, B., Gui. X., and Xu, H. (2011). "Bufalin and cinobufagin induce apoptosis of human hepatocellular carcinoma cells via fas- and mitochondriamediated pathways," Cancer Science 102(5), 951-958. DOI: 10.1111/j.13497006.2011.01900.x

Sajap, A. S., Lardizabal, M. L. T., Ahmad, F. B., and Sahri, M. H. (2006). "Feeding response of subterranean termite, Coptotermes curvignathus (Isoptera: Rhinotermitidae) to Azadirachta excelsa (Meliaceae) extractives and its timber," Sociobiology 48(2), 447-455. DOI:10.1590/S0085-56262006000100020

Soylu, E. M., Kurt, S., and Soylu, S. (2010). "In vitro and in vivo antifungal activity of essential oils of various plants against tomato grey mould disease agent Botrytis cinerea," International Journal of Food Microbiology 143(3), 183-189. DOI: 10.1016/j.ijfoodmicro.2010.08.015

Sun, M., Ma, X. X., Yao, Q. X., and Wang, R. C. (2011). "GC-MS and TG-FTIR study of petroleum ether extract and residue from low temperature coal tar," Energy and Fuels 25, 1140-1145. DOI: 10.1021/ef101610z

Xu, G. Q., Wang, L. H., Liu, J. L., and Wu, J. Z. (2013). "FTIR and XPS analysis of the changes in bamboo chemical structure decayed by white-rot and brown-rot fungi," Applied Surface 280, 799-805. DOI: 10.1016/j.apsusc.2013.05.065 
Zhao, X., Wang, J., Wang, L., Ren, S. M., Wang, Y. M. (2021). "Preparation and properties of nano- $\mathrm{TiO}_{2}$-Chinese herbal medicine composite wood," BioResources 16(2), 4252-4274. DOI:10.15376/biores.16.2.4252-4274

Article submitted: September 28, 2021; Peer review completed: October 25, 2021;

Revised version received and accepted: November 22, 2021; Published: November 30, 2021.

DOI: $10.15376 /$ biores.17.1.592-603 